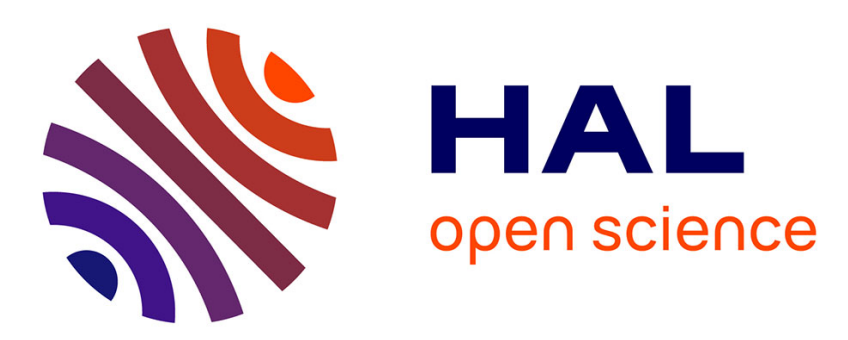

\title{
Is the Cape Roux marine protected area (Saint-Raphaël, Mediterranean Sea) an efficient tool to sustain artisanal fisheries? First indications from visual censuses and trammel net sampling
}

\author{
Catherine Seytre, Patrice Francour
}

\section{To cite this version:}

Catherine Seytre, Patrice Francour. Is the Cape Roux marine protected area (Saint-Raphaël, Mediterranean Sea) an efficient tool to sustain artisanal fisheries? First indications from visual censuses and trammel net sampling. Aquatic Living Resources, 2008, 21, pp.297-305. hal-00386302

\section{HAL Id: hal-00386302 \\ https://hal.univ-cotedazur.fr/hal-00386302}

Submitted on 20 May 2009

HAL is a multi-disciplinary open access archive for the deposit and dissemination of scientific research documents, whether they are published or not. The documents may come from teaching and research institutions in France or abroad, or from public or private research centers.
L'archive ouverte pluridisciplinaire HAL, est destinée au dépôt et à la diffusion de documents scientifiques de niveau recherche, publiés ou non, émanant des établissements d'enseignement et de recherche français ou étrangers, des laboratoires publics ou privés. 


\title{
Is the Cape Roux marine protected area (Saint-Raphaël, Mediterranean Sea) an efficient tool to sustain artisanal fisheries? First indications from visual censuses and trammel net sampling
}

\author{
Catherine Seytre and Patrice Francour ${ }^{\mathrm{a}}$ \\ EA 4228 ECOMERS, Université de Nice-Sophia Antipolis, Parc Valrose, 06108 Nice Cedex 2, France
}

Received 18 September 2007; Accepted 30 June 2008

\begin{abstract}
In recent decades, marine reserves have been established either to protect ecosystem structure and biological diversity or to serve as management tools to counter the overexploitation of fish stocks. The Cape Roux marine protected area (MPA), in the Mediterranean Sea, was established in December 2003 for the management of artisanal fisheries and enhancement target fish stocks.

Monitoring of littoral fish assemblages (0-30 m depth) in this zone began one year after the MPA was set up. The survey was conducted at 6 stations, located inside and outside the MPA, using three methods: underwater visual census (UVC) on transects, UVC using a new fish assemblage survey technique (FAST), and experimental net fishing performed by a fisherman. The FAST indices were derived from visual censuses, performed along a random pathway, scoring species on a presence/absence basis and size on a 2-class basis. Indices were calculated seasonally, by applying "weights" according to species and size. This study presents results obtained between October 2005 and June 2007. In the protected area, the experimental fishing yielded significantly higher abundance and species richness, and the FAST method highlighted a decrease in seasonal fluctuations. These two complementary methods (UVC and experimental fishing) revealed the early changes in fish assemblages in response to protection. The FAST method employed here seems to be relevant for the study of artisanal fishery target fishes, as a low-cost and sensitive UVC method.
\end{abstract}

Key words: Small-scale fishery / Fish diversity / Underwater visual census methods / Marine protected area / Mediterranean Sea

Résumé - L'aire marine protégée du cap Roux (Saint-Raphaël, Méditerranée) est-elle un outil efficace pour soutenir la pêche artisanale? Premières indications obtenues par comptages visuels et pêches expérimentales. Au cours des dernières décennies, des réserves marines ont été créées pour protéger la structure des écosystèmes et la diversité biologique ou comme outil de gestion des pêches pour contrer la surexploitation des stocks de poissons. L'aire marine protégée du cap Roux (Méditerranée, Saint-Raphaël) a été créée en décembre 2003, dans un but de gestion de la pêche artisanale afin de reconstituer des stocks exploités. Le suivi des peuplements de poissons de la zone littorale (0-30 $\mathrm{m}$ de profondeur) a débuté un an après la mise en place du cantonnement de pêche et sur 6 stations réparties à l'intérieur et à l'extérieur de la zone protégée. Trois méthodes sont utilisées : des comptages visuels en plongée sousmarine soit le long de transects, soit selon une nouvelle méthode dite : «Fish Assemblage Survey Technique (FAST)», ainsi que des pêches expérimentales au filet tramail, effectuées par un pêcheur professionnel. L'indice FAST est calculé de façon saisonnière sur les peuplements de poissons ciblés, en fonction des espèces, selon leur présence/absence, et selon 2 classes de taille.

Cette étude présente les résultats obtenus entre octobre 2005 et juin 2007. Dans la zone protégée, la quantité de poissons pêchés et la richesse spécifique sont significativement plus grandes, et les fluctuations saisonnières observées par la méthode FAST, plus faibles. Ces méthodes d'échantillonnage (visuelles et pêches expérimentales) permettent d'observer la mise en place d'un « effet réserve ». La méthode FAST semble être pertinente, peu onéreuse, sensible et facile à mettre en oeuvre pour étudier les effets de la pêche artisanale sur les peuplements de poissons.

a Corresponding author: patrice.francour@unice.fr 


\section{Introduction}

In recent years, there has been a rapid increase in the number of marine protected areas (MPAs) defined. The new generation of marine protected areas are mainly multiple-use reserves accommodating many different stakeholders, each with their own set of objectives: (1) protecting biodiversity and habitats, (2) facilitating the recovery of damaged areas, (3) preserving threatened species, (4) restocking overexploited marine species and (5) supporting tourism and education (e.g. Agardy 1994; Francour et al. 2001; Guidetti 2002; Gell and Roberts 2003; Halpern 2003). In the north-western Mediterranean Sea, traditional fishing techniques involve small scale fisheries, well suited to the heterogeneity of the littoral area (seagrass bed, sand and rocky areas, seamount and cliffs) (Catanzano et al. 2000). These small-scale fisheries are characterized by the use of longline and trammel nets; different mesh sizes are used depending on the fishes targeted. Through recent centuries, traditional management by fishermen has avoided a situation of overfishing from being reached.

Today, however, the effectiveness of traditional fisheries management to ensure acceptable levels of fishery sustainability is greatly impeded by various sources of uncertainty, including the creation of new harbours, increasing littoral anthropic impacts and the development of recreational activities (angling and spearfishing) (Carr and Raimondi 1999). There has consequently been a recession in the small-scale fishery sector (Juanes 2001).

The definition of marine areas with total fishing prohibition (no-take areas) is considered as the most relevant means of sustaining fisheries (Dugan and Davis 1993; Olver et al. 1995; Sumaila 1998; Jennings 2001; Gell and Roberts 2003). However, in the north-western Mediterranean, and particularly along French coasts, sustaining artisanal fisheries is not the main objective of MPAs (Francour et al. 2001). In addition, although the effect of marine reserves on fish assemblages are now well studied and known (e.g. García-Rubies and Zabala 1990; Dufour et al. 1995; Francour 1994; Halpern and Warner 2002; but see Côté et al. 2001), the benefits of protected areas for local fisheries are more difficult to assess (Roberts and Polunin 1991; Russ and Alcala 1996; Jennings 2001; Abesamis et al. 2006) and pertinent survey methods are needed, particularly for small-scale fisheries.

Guidetti (2002) pointed out that sampling to detect and measure the expected effects of protection on commercial fishes (target fishes) is made difficult by natural variability (spatial and temporal). Furthermore, Gell and Roberts (2003) considered that the main criticism against the use of marine reserves for fisheries management is that most commercial species are too mobile to benefit from the fishing prohibition, except in very specific cases like small-scale fisheries. In addition, despite the popularity of marine reserves as management tools, decisions on the design and location of most existing reserves have largely been the result of political and sociological processes (Francour et al. 2001; Halpern 2003).

Created as a management tool in December 2003 to sustain local small-scale fisheries, the Cape Roux MPA, a no-take area, has been monitored since 2005. A three-year monitoring of fish assemblages was carried out to assess the efficiency of this new MPA.
The implementation of the Cape Roux marine reserve by fishermen from Saint-Raphaël Prud'homie de Pêche was a policy decision. However, this MPA is located in a remote area (no littoral building development), with shallow bays covered by dense $P$. oceanica beds and deeper rocky areas covered by undamaged coralligenous concretions.

We hypothesized that, from a fisherman's point of view, efficiency of a MPA would be demonstrated if densities of commercial fish species were greater inside the protected zone than outside; so that size and density dependent processes, such as spawning and spillover, could then be enhanced (Russ and Alcala 1996; Abesamis et al. 2006).

This study was carried out using experimental net fishing and underwater visual census methods. As there was no pertinent indicator of target fish stock restoration for local fisheries, a new UVC method was used. Results obtained by the different sampling techniques were then compared.

\section{Material and methods}

\subsection{Study site}

The 450 ha Cape Roux MPA is located between Cannes and Saint-Raphaël (France, north-western Mediterranean) and extends from the shore to the $100 \mathrm{~m}$ isobath. No fishing of any kind is permitted (artisanal fishery, spearfishing, angling, etc.), but permanent surveillance has never been made. This zone was initially protected for a 4-year renewable period, starting from December 2003, and then renewed in January 2008 for an additional 6-year period. The seasonal monitoring described in the present study began in winter 2005 .

Three zones were considered in the present study: inside Reserve (R), outside North (N) and outside South (S) (Fig. 1). To allow spatial replication, an essential condition to prevent confusion in interpreting any differences between protected (R) and unprotected $(\mathrm{N}, \mathrm{S})$ areas, two stations were surveyed in each zone. This sampling allowed us to test for betweenstation variability, the "station effect". Moreover, all sampling stations (inside and outside the protected zone) are part of the same geographical and physical region: they present a similar biotope with a mix of Posidonia oceanica seagrass bed and rocky areas (cliff and seamount) covered by photophilic algae and coralligenous concretions. The two stations inside the reserve were located in the central part of the protected zone to avoid border effects. The stations outside the reserve were chosen symmetrically North and South.

\subsection{Sampling}

Two main methods were used to survey the fish assemblages (Table 1): experimental net fishing and underwater visual censuses (UVC).

\subsubsection{Experimental net fishing}

Standardized experimental net fishing was performed in October 2006 and June 2007 to obtain data that would be 
Table 1. Summary of sampling techniques.

\begin{tabular}{|c|c|c|c|}
\hline & UVC (Transects) & UVC (FAST method) & Experimental Net fishing \\
\hline Zones & \multicolumn{3}{|c|}{3 (inside reserve, outside reserve North and South) } \\
\hline Stations in each zone & 2 & 2 & $\begin{array}{l}2 \text { inside reserve, } 1 \text { outside } \\
\text { north and south }\end{array}$ \\
\hline Replicates & $10 /$ station & $6 /$ station & $6 /$ station \\
\hline Identified substrata & Posidonia oceanica & All & All \\
\hline Depth & $10-15 \mathrm{~m}$ & $0-20 \mathrm{~m}$ & $25-30 \mathrm{~m}$ \\
\hline Fish assemblage & $\begin{array}{l}\text { Small sized species } \\
\text { Not cryptic } \\
\text { Not fast swimming } \\
28 \text { species }\end{array}$ & $\begin{array}{l}\text { Commercial species } \\
28 \text { species }\end{array}$ & All \\
\hline Data acquisition & $\begin{array}{l}\text { Number of individuals / } \\
\text { transect } \\
3 \text { size classes (Small, } \\
\text { Medium, Large) }\end{array}$ & $\begin{array}{l}\text { Presence/absence } \\
2 \text { size classes (Small- } \\
\text { Medium, Large) }\end{array}$ & $\begin{array}{l}\text { Abundance of fishes / net } \\
\text { Species richness / net } \\
\text { Biomass / net }\end{array}$ \\
\hline Calculated variable & $\begin{array}{l}\text { Mean density / } 10 \mathrm{~m}^{2} \\
\text { Species richness }\end{array}$ & $\begin{array}{l}\text { Mean index } \\
\text { Cumulative index } \\
\text { Coefficient of variation } \\
\text { Species richness }\end{array}$ & $\begin{array}{l}\text { Mean density / net } \\
\text { Mean biomass / net } \\
\text { Mean species richness / net }\end{array}$ \\
\hline Sampling frequency & 1 year, 1 season (spring) & 2.5 years, 4 seasons & $\begin{array}{l}1 \text { year, } 2 \text { seasons (fall, } \\
\text { spring) }\end{array}$ \\
\hline
\end{tabular}

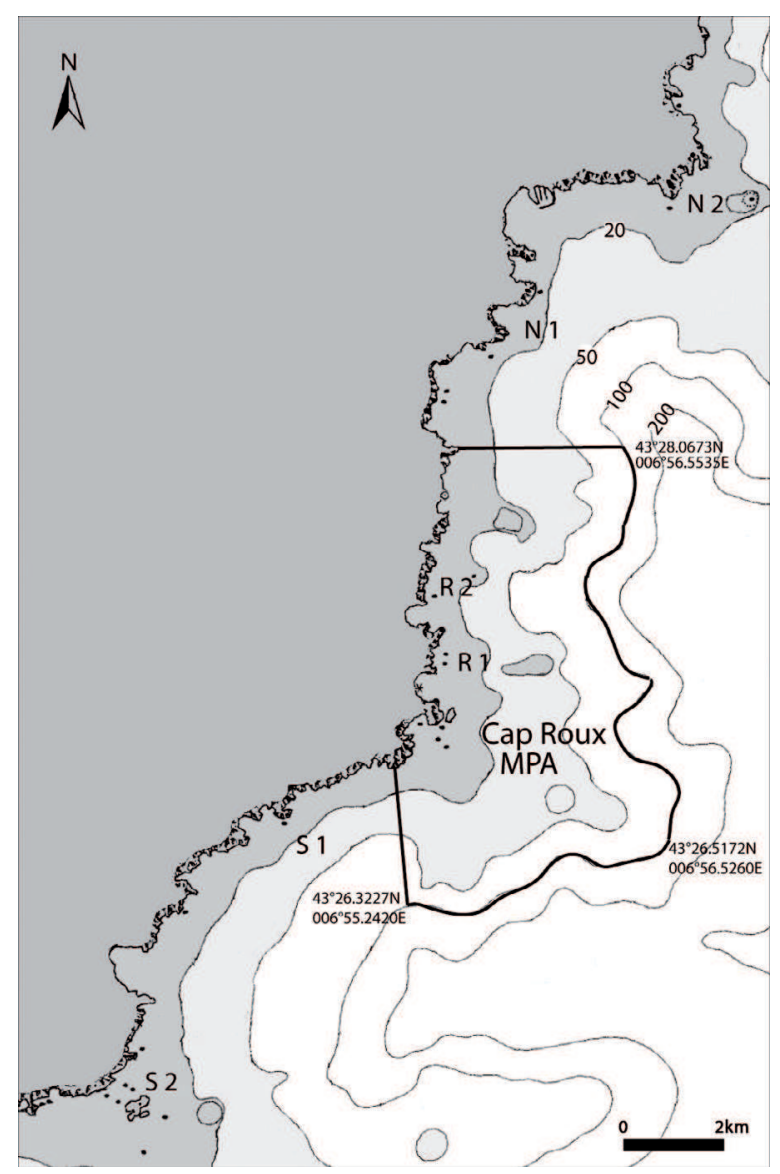

Fig. 1. The Cape Roux Marine Protected Area (Saint-Raphaël, Mediterranean Sea). The protected area is delimited by a full line. Two sampling stations are located inside the protected zone (R1 and $\mathrm{R} 2$ ), two outside to the north (N1 and N2) and two outside to the south (S1 and S2). trusted by fishermen and comparable with their own techniques.

Sampling was performed with a trammel net of medium mesh size, like those currently used by fishermen in the Cannes-Saint-Raphaël area. This net is made up of three netting panels: the two outer panels have large mesh openings and the inner panel has small mesh openings $(8.3 \mathrm{~cm}$ mesh size). Six 100 m-netting sections were used. Experimental fishing was performed at two stations in the protected zone and two outside it: one to the North and one to the South. The stations were randomly chosen within the zones so that the netting sections were placed at 25-30 m depth, over all types of substratum. The net chosen is representative of equipment used in this region.

Total biomass, fish abundance and species richness per 100 m-netting section $(n=6)$ were compared for the different stations and zones. Data were analyzed by analysis of variance (ANOVA) performed using Statistica 6.0 (Statsoft) with appropriate transformations required to respect the assumptions of ANOVA. For these three variables, zone was used as a fixed factor and station as a random factor nested within zone. Significant differences were identified using Tukey's HSD test.

\subsubsection{UVC methods}

- Transect censuses

We performed fish sampling along transects using the method described in Harmelin-Vivien et al. (1985) and Francour (1999). Twenty-eight fish species, representative of the Posidonia oceanica fish assemblage (Table 2) were selected and counted along transects $20 \mathrm{~m}$ long and $2 \mathrm{~m}$ wide in the Posidonia oceanica meadow between 10 and $15 \mathrm{~m}$ depth. A minimum of ten replicates were made at each station. Three size classes, defined by thirds of the maximum length of each species, were 
Table 2. List of fish species selected for sampling using both UVC methods: (i) along transects on Posidonia oceanica seagrass beds and (ii) FAST sampling, and (iii) fish caught by net fishing. FAST method: "A" all size classes of the species or "L" only large individual are considered as patrimonial and receive weight $=2$. Other species receive weight $=1$.

\begin{tabular}{|c|c|c|c|c|}
\hline & \multicolumn{3}{|c|}{ UVC } & \multirow[t]{2}{*}{ Net fishing } \\
\hline & \multicolumn{2}{|c|}{ FAST } & Transects & \\
\hline Coris julis & & & $*$ & \\
\hline Labrus merula & $*$ & & $*$ & $*$ \\
\hline Labrus viridis & $*$ & & $*$ & \\
\hline Symphodus cinereus & & & $*$ & \\
\hline Symphodus doderleini & & & $*$ & \\
\hline Symphodus mediterraneus & & & $*$ & \\
\hline Symphodus melanocercus & & & $*$ & \\
\hline Symphodus ocellatus & & & $*$ & \\
\hline Symphodus roissali & & & $*$ & \\
\hline Symphodus rostratus & & & $*$ & \\
\hline Symphodus tinca & $*$ & & $*$ & $*$ \\
\hline Boops boops & & & $*$ & $*$ \\
\hline Dentex dentex & $*$ & $\mathrm{~L}$ & $*$ & \\
\hline Diplodus annularis & $*$ & & $*$ & $*$ \\
\hline Diplodus cervinus & $*$ & & & \\
\hline Diplodus puntazzo & $*$ & & * & $*$ \\
\hline Diplodus sargus & $*$ & & $*$ & \\
\hline Diplodus vulgaris & $*$ & & $*$ & $*$ \\
\hline Oblada sp. & & & $*$ & \\
\hline Pagellus acarne & & & & $*$ \\
\hline Pagrus pagrus & $*$ & & & $*$ \\
\hline Sarpa salpa & $*$ & & $*$ & \\
\hline Sparus aurata & $*$ & $\mathrm{~L}$ & & \\
\hline Spondyliosoma cantharus & $*$ & & $*$ & $*$ \\
\hline Scorpaena porcus & & & $*$ & $*$ \\
\hline Scorpaena notata & & & $*$ & $*$ \\
\hline Scorpaena scrofa & $*$ & & & $*$ \\
\hline Epinephelus marginatus & $*$ & A & & \\
\hline Serranus cabrilla & $*$ & & $*$ & \\
\hline Serranus scriba & $*$ & & $*$ & \\
\hline Bothus podas & & & & \\
\hline Chelidonichthys lastoviza & & & & $*$ \\
\hline Chromis chromis & & & $*$ & \\
\hline Conger conger & $*$ & & & $*$ \\
\hline Dicentrarchus labrax & $*$ & $\mathrm{~L}$ & & \\
\hline Mugilidae & $*$ & & $*$ & $*$ \\
\hline Mullus surmuletus & $*$ & & $*$ & $*$ \\
\hline Muraena helena & $*$ & & & $*$ \\
\hline Phycis phycis & $*$ & & & $*$ \\
\hline Sciaena umbra & $*$ & A & & $*$ \\
\hline Seriola dumerili & $*$ & & & $*$ \\
\hline Sphyraena viridensis & $*$ & & & \\
\hline Spicara sp. & & & $*$ & \\
\hline Torpedo marmorata & $*$ & & & $*$ \\
\hline Uranoscopus scaber & & & & $*$ \\
\hline Zeus faber & $*$ & & & $*$ \\
\hline
\end{tabular}

recorded. Two stations were surveyed for each zone (Reserve, North, and South). The transect UVC method allowed density to be computed as the number of individuals $/ 10 \mathrm{~m}^{2}$, and relative species richness as the number of species observed out of the 28 on the list.

Data were analyzed by permutational MANOVA (PERMANOVA) for the Zone factor (3 levels: R, N, S) with the PERMANOVA+ package for PRIMER 6 software (Clark and Warwick 2001; Anderson and Gorley 2007). A Bray-Curtis matrix of similarity was applied on square-root-transformed data.

\section{- FAST Indices}

Transect UVC methods do not accurately sample large and mobile species, i.e. most target species (Harmelin-Vivien and Francour 1992). We therefore used an additional UVC method: the Fish Assemblage Survey Technique (FAST), developed to take account of the main species targeted by smallscale fisheries (Francour in prep.). The data acquisition for each station consisted of six 15-minute visual censuses by SCUBA divers, performed over all kinds of substratum (sand, seagrass, rock) between 0-20 m depth, along a random pathway. The censuses were performed on a presence/absence basis and on a 2-sizeclass basis (large fish, i.e. longer than $2 / 3$ of the maximum size, and small/medium fish, smaller than $2 / 3$ of maximum size). Maximum length of each species was obtained from fishbase.org. The 28 species selected (Table 2) are all targeted by fishermen and recreative fishery (net fishing, spearfishing, angling, etc.). The two size classes and number of censuses were chosen to make the FAST a rapid and relevant assessment method. Censuses were spread over 2 days.

An index was calculated, applying weights according to species and size. "Patrimonial" species received a higher weight $(\times 2)$ than the others $(\times 1)$. We considered patrimonial species to be those with a high commercial value or those that were endangered (Epinephelus marginatus and Sciaena umbra). For several species, a single size class (the largest) was considered as patrimonial (Dentex dentex, Sparus aurata and Dicentrarchus labrax). A Mean Index (MI) was computed as the average of the 6 indices, and a Coefficient of Variation (CV) was computed for the 6 censuses. A Cumulative Index (CI) was calculated after pooling the 6 censuses. The Relative Species Richness (RSR) was also computed, after pooling the 6 censuses, as the number of species observed among those listed. Values of Mean and Cumulative Index were expressed as a percentage of the maximum theoretical value (value obtained if all the species and both size classes were observed). These 4 indices allow the fish assemblage to be characterized and the different zones to be compared. The Mean Index represents fish density and size, while CV represents the assemblage stability. The Cumulative Index represents richness in species and in large individuals. The FAST index was computed seasonally from the beginning of 2005 (though spring 2005 is missing for the outside reserve North site). For each zone, the FAST parameters were calculated as the arithmetic mean of the two station values (geometric mean for the CV).

To compare the FAST index with the results from raw census data, PERMANOVA for the zone factor were performed separately on the raw data from each year (2005, 2006 and 2007). The two stations of each zone were pooled and 
similarity between and within zones was compared. A permutational multivariate dispersion test (PERMDISP) was then used to test within-group dispersion among groups (Anderson 2006). As the censuses were based on presence/absence, the matrix was composed of: 0 , for absence; 1 , if one size class was observed; and 2, if both size classes were observed. Analyses were performed on a Bray-Curtis matrix of similarity.

\section{Results}

\subsection{Experimental net fishing}

Species caught during the October 2006 and June 2007 net fishing are given in Table 2. Total biomass, fish abundance and species richness per netting section showed the same pattern, with very low values outside the MPA (Fig. 2). One of the inside reserve stations (R1) always presented higher values than the outside reserve stations. In October 2006, the second inside reserve station R2 showed no significant differences compared with the outside reserve stations. However, in June 2007, parameters calculated for R2 were not significantly different from those of R1 (Table 3). Very low values were observed for the North zone.

\subsection{Posidonia oceanica (UVC-transects)}

No significant differences were found for Station factor ( $p=0.239$ ) or Zone factor ( $p=0.467)$ using the nested PERMANOVA. The PERMDISP dispersion test showed no significant differences for Zone ( $p=0.257)$ or Station groups $(p=0.296)$.

\subsection{Fish Assemblage Survey Technique (UVC-FAST)}

Seasonal fluctuations of the Mean Index (Fig. 3) were observed, with little difference among the three zones. However, values were slightly higher inside the protected zone than outside it in the 2006 and 2007 winter periods. The coefficient of variation associated with Mean Index was relatively stable outside the MPA, while it was much more variable inside the MPA from autumn 2005. The Cumulative Index was almost always higher inside the MPA and did not exhibit high seasonal fluctuations there. The relative species richness showed lower seasonal fluctuations inside the MPA than outside, as for the Cumulative Index. However, warm season values were no different inside and outside the protected zone.

The PERMANOVA applied on FAST censuses raw data (Table 4) revealed a highly significant difference between zones in 2006 and 2007, but not in 2005. The dispersion test was not significant in 2005 and only weak evidence of a difference was observed in 2006 and 2007 ( $p=0.050$ and 0.055).

The PERMANOVA pair-wise comparisons performed for 2006 showed significant differences between the Reserve and the outside reserve North or South zones, whereas no difference was observed between the two unprotected zones. In 2007, significant differences were observed whatever pair was considered. The PERMIDISP pair-wise comparisons were
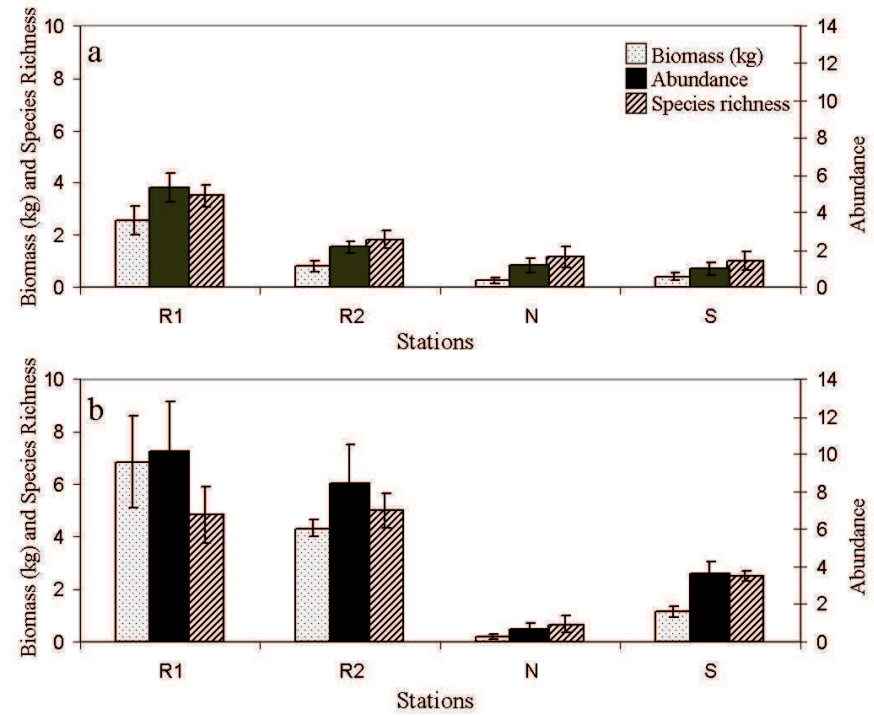

Fig. 2. Results of experimental net fishing carried out at the Cape Roux MPA in (a): October 2006 and (b): June 2007. Data are means per $100 \mathrm{~m}$-netting section, $N=6$, error bars are standard errors. Biomass and species richness values are given on the left scale, abundance on the right scale.

only significant for the pairs: Reserve/outside North in 2006 and Reserve/outside South in 2007. Within zone groups, the average similarity was higher outside the reserve than inside it (Table 4). The average similarities between zones showed that similarities were higher between the two unprotected zones.

\section{Discussion}

The absence of anthropization and the physical characteristics of the region where this MPA was implemented led to expectations about how it could achieve target fish stock restoration to sustain local fisheries. Our hypotheses were (i) that this MPA, although very recent, could produce an effect on inside reserve target fish assemblages; and (ii) that such a protected zone would have the ability to sustain surrounding fisheries. To answer to these questions, two points needed special consideration: the use of a pertinent fish assemblage indicator and the interpretation of the results from the standpoint of fishermen.

The UVC method along transects on seagrass beds did not show significant differences between protected and unprotected zones during this 3-year monitoring period. Transects were performed only on Posidonia oceanica seagrass bed: this substratum had been chosen to limit spatial heterogeneity and problems of result interpretation. However, Francour (1994) pointed out that reserve effect is less clear for fish assemblages in Posidonia oceanica meadows than in rocky areas. Conversely, seagrass beds exhibit a buffer effect characterized by a decrease in density or species richness variations in the protected zone.

In the present study, no buffer effect was demonstrated. No difference was observed in multivariate dispersion inside and outside the MPA, meaning that the variability between 
Table 3. Results of experimental net fishing. Biomass, fish abundance and species richness were tested using analysis of variance and differences identified with Tukey's HSD test. Four stations were compared: 2 inside reserve (R1, R2), 1 outside reserve South (S) and 1 outside reserve North $(\mathrm{N})$. Lines represent the absence of significant differences.

\begin{tabular}{|c|c|c|c|c|c|c|c|c|}
\hline \multirow[b]{2}{*}{ Total biomass } & \multicolumn{4}{|c|}{ October 2006} & \multicolumn{4}{|c|}{ June 2007} \\
\hline & $\mathrm{R} 1$ & $\underline{\mathrm{R} 2}$ & $\mathrm{~S}$ & $\mathrm{~N}$ & $\overline{\mathrm{R} 1}$ & $\underline{\mathrm{R} 2}$ & $\mathrm{~S}$ & $\mathrm{~N}$ \\
\hline Fish abundance & $\mathrm{R} 1$ & $\underline{\mathrm{R} 2}$ & $\mathrm{~S}$ & $\mathrm{~N}$ & $\overline{\mathrm{R} 1}$ & $\underline{\mathrm{R} 2}$ & $\overline{\mathrm{S}}$ & $\overline{\mathrm{N}}$ \\
\hline Species richness & $\mathrm{R} 1$ & $\underline{\mathrm{R} 2}$ & $\mathrm{~S}$ & $\mathrm{~N}$ & $\overline{\mathrm{R} 1}$ & $\underline{\mathrm{R} 2}$ & $\mathrm{~S}$ & $\mathrm{~N}$ \\
\hline
\end{tabular}
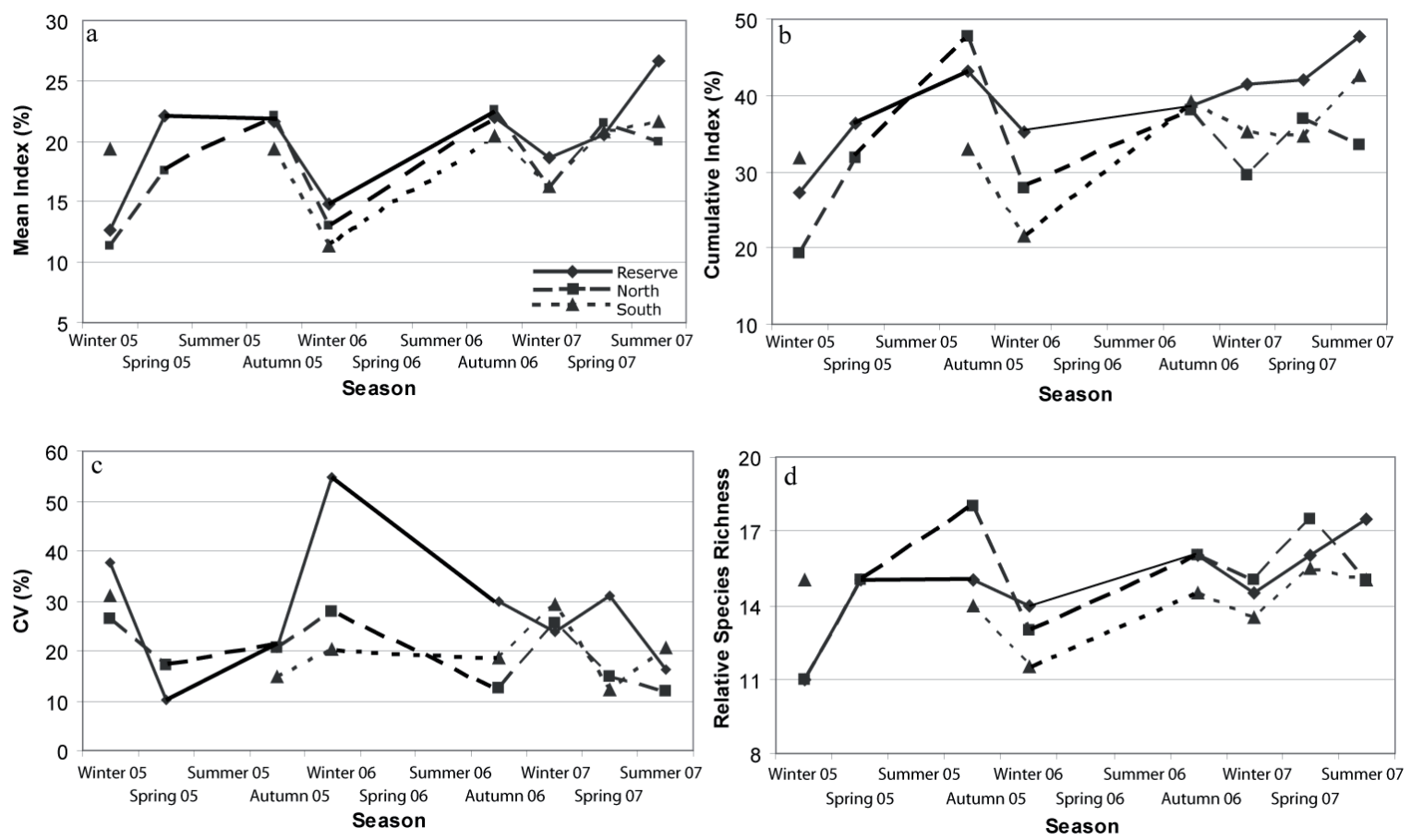

Fig. 3. Fish Assemblage Survey Technique (FAST) results between October 2005 and June 2007, inside and outside the Cape Roux protected zone. Results are expressed as a percentage of the maximum theoretical value, except for the relative species richness. (a) Mean Index, (b) Cumulative Index, (c) Coefficient of Variation of the Mean Index, (d) Relative Species Richness. Inside reserve values are represented with full lines, outside reserve North with broken lines and outside reserve South by dotted lines.

transects was not significantly different from one station to another. The lack of statistical difference between Posidonia oceanica fish assemblages inside and outside the marine reserve may be because (1) the prohibition of fishing was too recent, or (2) poaching occurred due to the lack of permanent surveillance. Species targeted by the recreative fishery belonged to: Serranidae, Labridae (mostly Coris julis), which are sensitive to angling; and Sparidae or Labridae (Labrus genera), which are targeted by spearfishing. These two hypotheses should probably be considered simultaneously.

Contrastingly, the two other sampling methods, FAST and experimental fishing, showed differences between the protected and the non-protected zones.

The FAST Cumulative Index was higher and less variable through the year inside the reserve than outside (North and South), although the Mean Index was not clearly different between the three zones. This means that in a cumulative way, pooling the 6 censuses by station, there are more species or larger fishes inside the marine reserve than outside, but these are still over-dispersed; as confirmed by the high value of the coefficient of variation. Moreover, as the Relative Species Richness was not higher in the protected zone compared with outside, the differences observed between the Mean Index and the Cumulative Index could be due to a combined effect of species richness and size. We do not consider that substratum heterogeneity between zones can explain these differences, as the whole region studied belongs to the same geographical and physical zone and because all substratum were covered.

The difference of pattern between the outside reserve zones North and South, in particular since winter 2007 for the $\mathrm{Cu}$ mulative Index, could be due to fishing pressure fluctuations. More data on fishing pressure are needed to explain these differences. We have to consider that small-scale fisheries are able to switch from one target and type of fishing equipment to another, and therefore have a varying impact on fish stocks. The observations made with the FAST for the last year outside 
Table 4. Results of multivariate analyses applied on FAST census raw data: permutational MANOVA and dispersion test results for the zone factor (N: outside reserve North, S: outside reserve South and $\mathrm{R}$ : inside reserve) and average similarities within and between zone groups given by the PERMANOVA test.

\begin{tabular}{|c|c|c|c|}
\hline \multicolumn{4}{|c|}{ Permutational MANOVA } \\
\hline & $\begin{array}{l}\text { Zone } \\
\text { considered }\end{array}$ & PERMANOVA & PERMDISP \\
\hline 2005 & All & $0.0568(\mathrm{~ns})$ & $0.972(\mathrm{~ns})$ \\
\hline 2006 & All & $0.0001(* * *)$ & $0.0499(*)$ \\
\hline 2007 & All & $0.0001(* * *)$ & $0.0552(\mathrm{~ns})$ \\
\hline \multicolumn{4}{|c|}{ Pair-wise tests } \\
\hline \multirow[t]{3}{*}{2006} & N.S & $0.427(\mathrm{~ns})$ & $0.311(\mathrm{~ns})$ \\
\hline & N.R & $0.0002(* * *)$ & $0.0133(*)$ \\
\hline & S.R & $0.0001(* * *)$ & 0.1721 (ns) \\
\hline \multirow[t]{3}{*}{2007} & N.S & $0.0068(* * *)$ & \\
\hline & N.R & $0.0001(* * *)$ & \\
\hline & S.R & $0.0001(* * *)$ & \\
\hline \multicolumn{4}{|c|}{$\begin{array}{l}\text { Average similarities within and between } \\
\text { zone groups using the PERMANOVA test }\end{array}$} \\
\hline & $\mathrm{N}$ & $\mathrm{S}$ & $\overline{\mathrm{R}}$ \\
\hline $\mathrm{N}$ & 72.3 & & \\
\hline $\mathrm{S}$ & 72.2 & 72.7 & \\
\hline $\mathrm{R}$ & 68.9 & 69.4 & 67.7 \\
\hline
\end{tabular}

the protected zone need to be confirmed with further censuses. If we consider the 4 FAST indices together, the trends observed are coherent with an expected reserve effect: changes appear in the assemblage with a noticeable decrease in seasonal fluctuations. Cold season values were thus lower inside the MPA than outside. The FAST seems to be a relevant tool for detecting early changes in fish assemblages due to reserve effect.

Moreover, the FAST observations are confirmed by the tests performed on the raw census data: differences between zones were observed (after 2005). The trends observed on the FAST index graphs are confirmed by the analyses, showing differences between zones and higher variability within the protected zone than outside.

For the methodological approach, the interest of computing the FAST indices compared with raw census data are: (1) giving results more adapted to fishermen's expectations, taking into account the economic value of the fish species; (2) better consideration of the ecological issues: weights give an account of size dependent processes, like spawning, and also the status of endangered species.

Similarly, for experimental fishing, very low abundances were measured outside the MPA, whatever the season. This trend is consistent with the high fishing pressure exerted in this zone (unpublished data from the Saint-Raphaël Prud'homie de Pêche). The total fishing prohibition inside the reserve, even if some poaching is possible and probable, allowed us to observe a clear reserve effect, at least in June 2007. The two periods exhibited the same pattern: higher abundance, richness and biomass inside the protected zone than outside it. The differences observed between the R1 station and the outside reserve stations remained the same in October 2006 and June 2007. For the second reserve station, more observations would be needed to separate a season effect from a growing reserve effect.
As for the FAST index, the seasonal difference observed could be due to seasonal movement of target fishes and/or to the strong fishing pressure exerted during the spring and summer period outside and at the MPA border.

Experimental fishing data are consistent with the FAST results. These two methods are complementary. Experimental fishing can also catch a part of the fish assemblage that is difficult to sample with UVC, like nocturnal species. This could explain the extent of the differences between zones given by experimental net fishing in comparison with FAST. A large proportion of the net catches were Scorpaenidae, often underestimated during visual censuses because of their camouflage.

The fish species sampled by the FAST method are all species targeted by fishermen and recreative fishery. In the trammel nets, the most abundant fish belonged to the genera Scorpaena, Spondyliosoma, Diplodus and Muraena. Neither method sampled prey fishes, but census along transects in Posidonia oceanica meadows took these small species into account (e.g. small Symphodus spp.). The reserve effect has been demonstrated mainly for target species (e.g. Polunin and Roberts 1993; Macpherson 2000; Jouvenel and Pollard 2001) but not for prey species, which are less sensitive to the protection measures. This may be due to a trophic cascade effect (see Pinnegar et al. 2000). Preys seem to be more sensitive to predator abundance, which increases with fishing prohibition, than to the fishing prohibition itself.

Now, can we say there is a positive effect of this MPA from the fishermen's point of view? To assess the effectiveness of the MPA effect on fish assemblage, the monitoring of the reserve effect following its implementation could be carried out using experimental fishing techniques and a sensitive UVC method, such as the proposed FAST method. The assemblages sampled with FAST yielded results closer to experimental net fishing than to traditional UVC on Posidonia oceanica transects. The target fishes, (e.g. Sparidae), and particularly large individuals, are the most sensitive to the reserve effect.

In the Mediterranean and indeed throughout the world, few data are available about the dynamics of the response of fish assemblages to protection. Gell and Roberts (review, 2003) showed that reserves and fishery closures benefit species as diverse as molluscs, crustaceans, and fish of a wide range of size, life history and mobility. Benefits develop within two to five years of reserve establishment and continue to build for decades. Most of the target species in the north-western Mediterranean are long-lived species (5 to 40 years). We can therefore hypothesize that a long term period (several decades) of fishing prohibition is necessary to reach a complete reserve effect that could lead to an increase in catches for fishermen outside the protected zone, as a density-dependent process. Consequently, short term prohibition of fishing does not sustain artisanal fisheries. However, the duration of this shortterm study should be sufficient to demonstrate that fish stock restoration has begun inside the protected zone, at least for the target species, and to convince fishermen of the utility of such MPAs.

The FAST values calculated inside the reserve are still lower than ones calculated for older MPAs such as the Natural Reserve of Scandola, Corsica (MPA created in 1975) 
and the National Park of Port-Cros (France, created in 1963) (Francour, unpublished data collected from 1999 to 2006).

The effectiveness of marine reserves in enhancing fish abundance may be largely related to the intensity of exploitation outside the reserve boundaries and to the composition of fish assemblages within these boundaries (Côté et al. 2001). The high fishing pressure exerted over the fish stocks to the North and the South of the MPA probably magnified the differences in net trammel yield between zones.

However, the Cape Roux marine reserve was implemented by fishermen from Saint-Raphaël Prud'homie de Pêche and it is very important, from a political point of view, for the analysis of reserve effect using sampling techniques trusted by fishermen. Involving fishermen in MPA management remains a crucial issue to ensure MPA success and potential stock restoration.

\section{Conclusion}

Halpern (2003) showed that relative impacts of reserves, such as the proportional differences in density or biomass, are independent of reserve size. However, this lack of relationship does not imply that we should rely only on small reserves for conservation and fishery management. The 450 ha Cape Roux marine reserve encompasses a high diversity of habitats (seagrass, sand, rocky areas) and presents a shore without buildings or harbours. This 3-year monitoring, carried out after the creation of the MPA, shows the start of fish assemblage recovery. The MPA, characterized by its surface, location and habitat diversity, could therefore to be a relevant tool to sustain small-scale fisheries in this region. A more complete stock recovery will however require a longer period of fishing prohibition, the maintenance of habitat diversity, and a reduction in the possible poaching. These three issues respectively imply: ensuring fishermen's cooperation, reducing damaging activities (e.g. boat anchoring), and developing permanent surveillance from land and sea.

Acknowledgements. This part of a $\mathrm{PhD}$ thesis is supported by grant from the "Région Provence-Alpes-Côtes d'Azur". We would like to thank Christian Decugis and Elisabeth Tempier from the St-Raphaël Prud'homie de Pêche for their commitment and Christian Ubbizzoni for carrying out the experimental fishing. We also wish to thank the divers P. Bodolis, J.-M. Cottalorda, J. Gratiot and P.-A. Mannoni, who helped us with the underwater observations.

\section{References}

Abesamis R.A., Russ G.R., Alcala A.C., 2006, Gradients of abundance of fish across no-take marine reserve boundaries: evidence from Philippine coral reefs. Aquat. Conserv. Mar. Freshw. Ecosyst. 16, 349-371.

Agardy M.T., 1994, Advances in marine conservation: the role of marine protected areas. Trends Ecol. Evol. 9, 267-270.

Anderson M.J., 2006, Distance based tests for homogeneity of multivariate dispersions. Biometrics. 62, 245-253.
Anderson M.J., Gorley R.N., 2007. PERMANOVA+ for PRIMER: Guide to software and statistical methods. Plymouth, PRIMERE.

Carr M.H., Raimondi P.T., 1999, Marine protected areas as a precautionary approach to management. CalCOFI Rep. 40, 71-76.

Catanzano J., Cunningham S., Rey H., 2000, Fishery management in the Mediterranean: an evaluation of French effort-based management systems. IIFET 2000. Oregon, USA, Proceedings, pp. 1-6.

Clark K.R., Warwick R.M., 2001, Change in marine communities: an approach to statistical analysis and interpretation. $2^{\text {nd }}$ edition, Plymouth, PRIMER-E Ltd.

Côté I.M., Mosqueira I., Reynolds J.D., 2001, Effects of marine reserve characteristics on the protection of fish populations: a meta-analysis. J. Fish Biol. 59 (suppl. A), 178-189.

Dufour V., Jouvenel J.-Y., Galzin R., 1995, Study of a Mediterranean reef fish assemblage. Comparisons of population distributions between depths in protected and unprotected areas over one decade. Aquat. Living Resour. 8, 17-25.

Dugan J.E., Davis G.E. 1993. Applications of marine refugia to coastal fisheries management. Can. J. Fish. Aquat. Sci. 50, 20292042.

Francour P., 1994, Pluriannual analysis of the reserve effect on ichthyofauna in the Scandola natural reserve (Corsica, northwestern Mediterranean). Oceanol. Acta 17, 309-317.

Francour P., 1999, A critical review of adult and juvenile fish sampling techniques in Posidonia oceanica seagrass beds. Naturalista Sicil. 23(suppl.), 33-57.

Francour P., Harmelin J.G., Pollard D., Sartoretto S., 2001, A review of marine protected areas in the northwestern Mediterranean region: sitting, usage, zonation and management. Aquat. Conserv. Mar. Freshw. Ecosyst. 11, 155-188.

García-Rubies A., Zabala M., 1990, Effects of total fishing prohibition on the rocky fish assemblages of Medes Islands marine reserve (NW Mediterranean). Sci. Mar. 54, 317-328.

Gell F.R., Roberts C.M., 2003, Benefits beyond boundaries: the fishery effects of marine reserves. Trends Ecol. Evol. 18, 448-455.

Guidetti P., 2002, The importance of experimental design in detecting the effects of protection measures on fish in Mediterranean MPAs. Aquat. Conserv. Mar. Freshw. Ecosyst. 12, 619-634.

Halpern B.S., 2003, The impact of marine reserves: do reserves work and does reserve size matter ? Ecol. Appl. 13, S117-S137.

Halpern B.S., Warner R.R., 2002, Marine reserves have rapid and lasting effects. Ecol. Lett. 5, 361-366.

Harmelin-Vivien M., Francour P., 1992, Trawling or visual censuses? Methodological bias in the assessment of fish populations in seagrass beds. PSZNI Mar. Ecol. 13, 41-51.

Harmelin-Vivien M., Harmelin J.G., Chauvet C., Duval C., Galzin R., Lejeune P., Barnabé G., Blanc F., Chevalier R., Duclerc J., Lassère G., 1985, Evaluation visuelle des peuplements et populations de poissons : méthodes et problèmes. Rev. Ecol. (Terre Vie) 40, 467-539.

Jennings S. 2001. Patterns and prediction of population recovery in marine reserves. Rev. Fish Biol. Fish. 10, 209-231.

Jouvenel J.-Y., Pollard D.A., 2001, Some effects of marine reserve protection on the population structure of two spearfishing targetfish species, Dicentrarchus labrax (Moronidae) and Sparus aurata (Sparidae), in shallow inshore waters, along a rocky coast in the northwestern Mediterranean sea. Aquat. Conserv. Mar. Freshw. Ecosyst. 11, 1-9. 
Juanes F. 2001, Mediterranean marine protected areas. Trends Ecol. Evol. 16, 169-170.

Macpherson E. 2000, Fishing effects on trophic structure of rocky littoral fish assemblages. in : Fishing down the Mediterranean food webs? CIESM Publ., Monaco, CIESM Workshop Ser. 12, 43-44.

Olver C.H., Shuter B.J., Minns C.K., 1995, Toward a definition of conservation principles for fisheries management. Can. J. Fish. Aquat. Sci. 52, 1584-1594.

Pinnegar J.K., Polunin N.V.C., Francour P., Chemello R., HarmelinVivien M., Hereu B., Milazzo M., Zabala M., 2000, Trophic cascades in fisheries and protected area management of benthic marine ecosystems. Environ. Conserv. 27, 179-200.
Polunin N.V.C., Roberts C.M., 1993, Greater biomass and value of target coral-reef fishes in two small Caribbean marine reserves. Mar. Ecol. Prog. Ser. 100, 167-176.

Roberts C.M., Polunin N.V.C., 1991, Are marine reserves effective in management of reef fisheries? Rev. Fish Biol. Fish. 1, 65-91.

Russ G.R., Alcala A.C., 1996, Do marine reserves export adult fish biomass? Evidence from Apo Island, central Philippines. Mar. Ecol. Prog. Ser. 132, 1-9.

Sumaila U.R., 1998, Protected marine reserves as fisheries management tools: a bioeconomic analysis. Fish. Res. 37, 287296. 